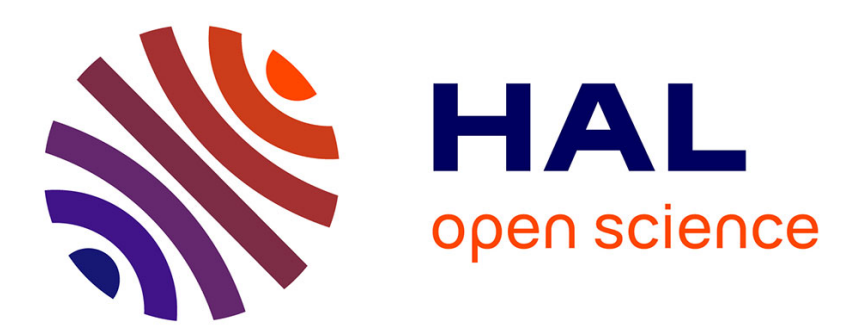

\title{
Toxicity of mycotoxins to honeybees and its amelioration by propolis
}

Guodong Niu, Reed Johnson, May Berenbaum

\section{To cite this version:}

Guodong Niu, Reed Johnson, May Berenbaum. Toxicity of mycotoxins to honeybees and its amelioration by propolis. Apidologie, 2011, 42 (1), pp.79-87. 10.1051/apido/2010039 . hal-01003572

\section{HAL Id: hal-01003572 \\ https://hal.science/hal-01003572}

Submitted on 1 Jan 2011

HAL is a multi-disciplinary open access archive for the deposit and dissemination of scientific research documents, whether they are published or not. The documents may come from teaching and research institutions in France or abroad, or from public or private research centers.
L'archive ouverte pluridisciplinaire HAL, est destinée au dépôt et à la diffusion de documents scientifiques de niveau recherche, publiés ou non, émanant des établissements d'enseignement et de recherche français ou étrangers, des laboratoires publics ou privés. 


\title{
Toxicity of mycotoxins to honeybees and its amelioration by propolis*
}

\author{
Guodong NiU, Reed M. JoHnson**, May R. BERENBAUM \\ Dept. Entomology, 320 Morrill Hall, University of Illinois, 505 S. Goodwin, 61801-3795, Urbana, USA
}

Received 28 July 2009 - Revised 26 December 2009 - Accepted 28 January 2010

\begin{abstract}
Honeybees (Apis mellifera) and their resource-rich nests are hosts to a wide range of saprophytic fungi, including species that produce mycotoxins. The toxicity of aflatoxin B1 (AB1) and ochratoxin A (OTA), products of Aspergillus species often found in honeybee hives, was evaluated and $\mathrm{LC}_{50}$ values for both toxins were calculated. Workers can tolerate a wide range of concentrations of both OTA and AB1. At low concentrations, AB1 $(1 \mu \mathrm{g} / \mathrm{g}$ and $2.5 \mu \mathrm{g} / \mathrm{g}$ diet $)$ and OTA $(1 \mu \mathrm{g} / \mathrm{g})$ did not have any apparent toxic effects on bees. Enhancement of the toxicity of $\mathrm{AB} 1$ by piperonyl butoxide (PBO), a known inhibitor of cytochrome P450 monooxygenases, indicates a role for P450s in AB1 detoxification in honeybees. Extracts of propolis, a complex mixture of plant-derived chemicals, including many flavonoids and other phenolic compounds, similarly ameliorated aflatoxin toxicity and delayed the onset of mortality. Collectively, these results suggest that tolerance of $\mathrm{AB} 1$ by honeybees may be due to $\mathrm{P} 450$-mediated metabolic detoxification. Propolis may serve a hitherto unrecognized role in honey bee health by enhancing the activity of P450 enzymes involved in mycotoxin detoxification.
\end{abstract}

honeybee / aflatoxin B1 / ochratoxin A / cytochrome P450 monooxygenases / piperonyl butoxide / propolis

\section{INTRODUCTION}

Honeybees (Apis mellifera) and their resource-rich nests are hosts to a wide range of saprophytic fungi. Fungi in the genus Aspergillus, for example, can colonize stored products in the hive, including pollen (González et al., 2005) and honey (Jimenez et al., 1994; Martins et al., 2003). Such fungi present a challenge to honeybees not only because they compete with honeybees for the stored food but because under certain conditions the fungi can produce mycotoxins that can cause toxicity in bees. Aspergillus ochraceus growing on pollen, e.g, produces both ochratoxins and aflatoxins (Medina et al., 2004). Aflatoxins at concentrations as low as

Corresponding author: M.R. Berenbaum, maybe@illinois.edu

* Manuscript editor: Bernd Grünewald

** Current address: University of NebraskaLincoln; Department of Entomology; 202 Entomology Hall; Lincoln, NE 68583, USA.
5 ppm can cause premature death of workers (Hilldrup and Llewellyn, 1979). In colonies weakened by other stresses, Aspergillus flavus can infect the bees themselves, gaining access to brood through the midgut and to adults through cuticular abrasions. Infection by this fungus manifests itself as a disease called stonebrood, typified by mummification of the lasvae (James and Pitt-Singer, 2008). Colonies are generally capable of recovering from such infections, depending on hygienic behavior and genetic identity (Gilliam and Vandenberg, 1988; Gilliam et al., 1989).

Although honeybees are more sensitive to the toxic effects of the mycotoxin aflatoxin B1 than Drosophila melanogaster and Musca domestica (Hilldrup and Llewellyn, 1978), the fact that colonies are often able to fend off infections is indicative of some capacity for coping with these mycotoxins, which may be frequently encountered in the hive environment. In many insect species, aflatoxins are metabolized by cytochrome P450 monooxygenases 
(P450s), heme-based enzymes that generally catalyze oxidative reactions that reduce lipophilicity and hence toxicity of a wide range of both natural and synthetic xenobiotics ( $\mathrm{Li}$ et al., 2007). Aflatoxins and several other mycotoxins are unusual, however, in that in many species $\mathrm{P} 450$-mediated metabolic reactions result in bioactivation, or an increase in toxicity, via conversion of the aflatoxin to the more toxic epoxide metabolite (Saner et al., 1996).

Species that naturally encounter aflatoxins in their environment display some degree of adaptation to mycotoxins in that they metabolize these compounds not to bioactivated epoxides but rather to nontoxic breakdown products. The corn earworm Helicoverpa zea, for example, frequently causes damage in its hostplants that leaves them vulnerable to opportunistic infection by Aspergillus spp. In the midgut, $H$. zea detoxifies aflatoxin B1 (AB1) via CYP321A1 (Niu et al., 2008). Even more tolerant of aflatoxins is the navel orangeworm Amyelois transitella. This species infests dried fruits and nuts, particularly almonds and pistachios, and appears to prefer fungus-infected fruit (Palumbo et al., 2008). This species can tolerate dietary levels of AB1 100-fold greater than levels that inhibit $H$. zea (Niu et al., 2009) and produces principally aflatoxicol as a metabolite. Neither this species nor the aflatoxin-tolerant codling moth Cydia pomonella produce AB1-8,9-epoxide, the principal bioactivated metabolite of $\mathrm{AB} 1$ (Lee and Campbell, 2000). Although P450mediated metabolism has been implicated in this tolerance, the specific $\mathrm{P} 450$ (s) responsible for this detoxification have not yet been identified in either species.

In this study, we set out to ascertain the degree to which $A$. mellifera can tolerate exposure to mycotoxins and to establish whether tolerance is associated with cytochrome P450mediated metabolism by using a known inhibitor of honeybee P450s, piperonyl butoxide, and a known inducer of honeybee P450s, propolis, the resinous "bee glue" that is a ubiquitous component of the hive. Johnson (2008) demonstrated that extracts of propolis administered orally to honeybees effects upregulation of three CYP6AS P450 genes, at least one of which is known to metabolize flavonoids found in honey, pollen and propolis (Mao et al., 2009). Understanding the mechanisms of resistance to mycotoxins may shed light on how this managed pollinator copes with chemical stresses.

\section{MATERIALS AND METHODS}

\subsection{Insects}

Honeybees were obtained from colonies containing multiply mated queens at the University of Illinois Bee Research Facility at Urbana (Champaign County), IL. Frames of late-stage pupae were taken from hives and transferred to a dark humid incubator at $32-34{ }^{\circ} \mathrm{C}$. Newly eclosed adults were brushed from frames every $24 \mathrm{~h}$ for immediate use in bioassays.

\subsection{Chemicals}

Aflatoxin B1 and ochratoxin A (OTA) were obtained from Sigma Co (St Louis, MO). Piperonyl butoxide (PBO) was purchased from Tokyo Kassie Kogyo (Tokyo, Japan). Analytical grade dimethyl sulfoxide (DMSO) was purchased from Fisher Scientific (Pittsburgh, PA). All solvents, including methanol, were of analytical reagent grade. $\mathrm{AB} 1$ and OTA were dissolved in DMSO as concentrated stock solutions and stored in $\mathrm{a}-20{ }^{\circ} \mathrm{C}$ freezer.

\subsection{Substrate carrier}

Chemicals to be tested were administered to bees by incorporation into "bee candy," made using equal weights of powdered sugar and concentrated sugar solution with a ratio of 2:1 sucrose to water (w/w). Granulated table sugar (sucrose) was ground in a blender for approximately $3 \mathrm{~min}$ to make powdered sugar. Approximately $5 \mathrm{~g}$ fresh candy was poured into a $2 \mathrm{oz}(56 \mathrm{~mL})$ plastic cup (Solo, Urbana, IL); mycotoxins or a vehicle control were incorporated into the wet candy, which was then allowed to harden for $30 \mathrm{~min}$.

To test effects of propolis on aflatoxin toxicity to honeybees, propolis was collected from hives in a forested area at Phillips Tract Research Area (Champaign Co., Illinois). Propolis was frozen in liquid nitrogen and then ground with a mortar and pestle and stored at $-20{ }^{\circ} \mathrm{C}$. Approximately $3 \mathrm{~g}$ of ground propolis was dissolved in $50 \mathrm{~mL}$ of hot methanol. Wax was precipitated from the cooled 
methanol extract and the remaining extract was concentrated to $5 \mathrm{~mL}$ by evaporation under a stream of air. Propolis solution was added to powdered sugar and the methanol was allowed to dry for $24 \mathrm{~h}$ before mixing with an equal mass of heavy sugar syrup to make candy with a final concentration of 50, 150 and $300 \mathrm{mg}$ propolis/g candy.

\subsection{Bioassays}

Newly eclosed workers were used for bioassays. Stocks of $10 \mu \mathrm{g} / \mu \mathrm{L}$ or $20 \mu \mathrm{g} / \mu \mathrm{L}$ of $\mathrm{AB} 1$ and OTA were dissolved in DMSO and stored at $-20^{\circ} \mathrm{C}$. Bee candy was used to test the oral toxicity of mycotoxins with and without synergists via bioassay. For all bioassays, approximately $3 \mathrm{~g}$ of unanaesthetized newly emerged bees were transferred quickly to a $6 \mathrm{oz}(188 \mathrm{~mL}$; Sweetheart, Owings Mills, MD) wax-coated paper cup into which the treated candy had been placed. The cups were then covered with cheesecloth and placed into a dark humid incubator at a temperature of $32-34{ }^{\circ} \mathrm{C}$. The mortality of bees was recorded every six hours until all bees had died.

To determine the oral $\mathrm{LC}_{50}$ of $\mathrm{AB} 1$ to bees, $\mathrm{AB} 1$ was incorporated into candy to achieve levels of 0.5 , $1,2.5,5,7,10,15$ or $20 \mu \mathrm{g} \mathrm{AB} 1$ per g candy; in an additional treatment, DMSO was added to bee candy as a control. To determine the $\mathrm{LC}_{50}$ of OTA to bees, candy containing 1, 5, 10, 20, 40, 60 or $80 \mu \mathrm{g} / \mathrm{g}$ OTA was prepared, along with control candy containing DMSO. To test the effects of the known $\mathrm{P} 450$ synergist piperonyl butoxide (PBO) on the toxicity of $\mathrm{AB} 1$ or OTA to bees, two concentrations of $\mathrm{PBO}(0.05 \%$ or $0.1 \% \mathrm{PBO})$ were tested in the presence of $\mathrm{AB} 1$ or OTA. For $\mathrm{AB} 1$ vs $\mathrm{PBO}$ bioassays, candy containing six different concentrations of chemicals was prepared: $0.1 \%$ DMSO, $10 \mu \mathrm{g} / \mathrm{g}$ AB1, 0.05\% PBO, 0.1\% PBO, $10 \mu \mathrm{g} / \mathrm{g} \mathrm{AB} 1$ supplemented with $0.05 \%$ or $0.1 \%$ PBO. For the bioassay comparing OTA and PBO, two doses of OTA (10 and $40 \mu \mathrm{g} / \mathrm{g}$ ) were tested and compared with corresponding doses of OTA supplemented with $0.05 \%$ or $0.1 \%$ PBO.

To determine the effects of propolis, which has been shown to induce a subset of cytochrome P450 monooxygenase enzymes involved in detoxification (Johnson, 2008), the toxicity of AB1 and OTA in propolis-treated candy was determined. Five $\mu \mathrm{l}$ of stock $\mathrm{AB} 1(20 \mu \mathrm{g} / \mu \mathrm{L})$ was incorporated into $5 \mathrm{~g}$ of plain candy to prepare the candy containing $20 \mu \mathrm{g} / \mathrm{g}$ $\mathrm{AB} 1$ or into $5 \mathrm{~g}$ of candy containing 50,150 and $300 \mathrm{mg} / \mathrm{g}$ of propolis and mixed until the toxin was homogeneously distributed in the fresh candy.
Candy treated with DMSO only and candy containing 50,150 or $300 \mathrm{mg} / \mathrm{g}$ propolis without $\mathrm{AB} 1$ were used as controls.

\subsection{Statistics}

The R statistical package (R Development Core Team, 2009) with MASS libraries (Venables and Ripley, 2002) was used for log-probit analysis. $\mathrm{LC}_{50}$ values with $95 \%$ confidence intervals were calculated using Fieller's method (Finney, 1971). Treatments with non-overlapping $95 \%$ confidence intervals for $\mathrm{LC}_{50}$ were considered significantly different. Survival data to determine effects of PBO or propolis on the toxicity of $\mathrm{AB} 1$ or OTA to bees were analyzed using SPSS statistical software (SPSS Inc., Chicago, IL). With the function of survival analysis in SPSS, the median time for survival was calculated for each treatment independently. To compare the data among groups in any given bioassay, the data from all treatments were compared with one-way analysis of variance (Tukey plot) using the function of survival analysis in the software package. In the bioassay testing the effects of PBO on the toxicity of AB 1 or OTA to honeybees, the $P$ value was calculated to compare effects of $A B 1$ or OTA in the presence or absence of the inhibitor. In the bioassay testing the effects of propolis extracts on the toxicity of AB1, the $P$ value was calculated to compare impacts of $\mathrm{AB} 1$ in the presence and absence of propolis. Comparisons yielding $p$ values equal to or less than 0.05 were considered to indicate significant differences.

\section{RESULTS}

\subsection{Toxicity of mycotoxins to $A$. mellifera}

None of the treatments containing AB1, even at the highest dose of $20 \mu \mathrm{g} / \mathrm{g}$, resulted in bee mortality in less than $24 \mathrm{~h}$ (Fig. 1). The low concentrations of AB1 $(1 \mu \mathrm{g} / \mathrm{g}$ and $2.5 \mu \mathrm{g} / \mathrm{g})$ did not have any apparent toxic effects on bees over the entire duration of the bioassays. The intermediate dose of AB1 $(5 \mu \mathrm{g} / \mathrm{g})$ caused less than $50 \%$ mortality after $72 \mathrm{~h}$. The high doses of $\mathrm{AB} 1(10,15$ and $20 \mu \mathrm{g} / \mathrm{g})$ caused over $90 \%$ mortality in $72 \mathrm{~h}$ (Fig. 1 ). The $\mathrm{LC}_{50}$ of AB1 (defined as the concentration causing $50 \%$ mortality of treated bees in $72 \mathrm{~h}$ ) was $6.76 \mu \mathrm{g} / \mathrm{g}(95 \%$ conf. int. $=5.86-7.69$; slope $=$ 


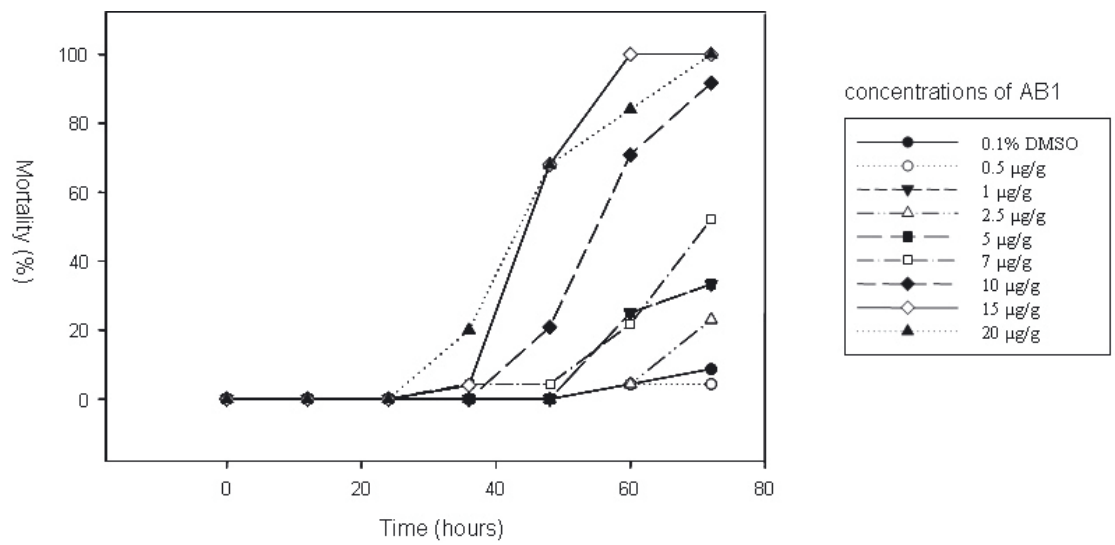

Figure 1. Mortality of Apis mellifera exposed to different concentrations of dietary aflatoxin B1 (AB1). Groups of approximately 30 newly eclosed workers were fed "bee candy" containing a range of concentrations of AB1 in DMSO and candy containing DMSO only. Each experiment was repeated three times (Tab. I); this figure graphically depicts the result of one replicate for visual clarity.

$4.32+/-0.30 ; \mathrm{X}^{2}=6.67 ; \mathrm{df}=4 ; \mathrm{n}=590$ ) (Fig. 3).

Bees also displayed tolerance of a wide range of concentrations of OTA. The low concentration of OTA $(1 \mu \mathrm{g} / \mathrm{g})$ did not have any apparent toxicity to bees and the treated bees lived as long as the control bees. As with the $\mathrm{AB} 1$ treatments, no bee mortality was observed, even at the highest concentrations, in less than $24 \mathrm{~h}$. Over time, mortality increased and concentrations equal to or greater than $10 \mu \mathrm{g} / \mathrm{g}$ caused $100 \%$ mortality after $72 \mathrm{~h}$. Most of treated bees died during the final 24 hours (from $48 \mathrm{~h}$ to $72 \mathrm{~h}$ ) (Fig. 2). The $\mathrm{LC}_{50}$ of OTA at 72 hours for bees was $5.04 \mu \mathrm{g} / \mathrm{g}(95 \%$ conf. int $=1.73-7.90 ;$ slope $=$ $1.11+/-0.28 ; \mathrm{X}^{2}=1.49 ; \mathrm{df}=2 ; \mathrm{n}=210$ ) (Fig. 3).

While both OTA and AB1 exhibit similar toxicity to bees, the slope of the probit lines for $\mathrm{AB} 1$ is substantially steeper than is the slope of the probit line for OTA, indicating that the response to OTA is more heterogeneous than the response to $\mathrm{AB} 1$.

\subsection{Effects of synergists on the toxicity of AB1 or OTA to bees}

Enhancement of the toxicity of $\mathrm{AB} 1$ and OTA by administration of PBO, a known in- hibitor of cytochrome P450 monooxygenases in bees (Johnson et al., 2006), indicates a role for P450s in mycotoxin metabolism in honeybees. Bees started to die earlier when consuming candy containing $10 \mu \mathrm{g} / \mathrm{g}$ AB1 supplemented either with $0.05 \%$ PBO or $0.1 \%$ PBO than did bees consuming candy supplemented with $10 \mu \mathrm{g} / \mathrm{g}$ AB1 alone (Tab. I). These results suggest that $\mathrm{P} 450$ s contribute to enzymatic detoxification of $\mathrm{AB} 1$ in honeybees.

In contrast with $\mathrm{AB} 1, \mathrm{PBO}$ did not show any synergistic effects on the toxicity of OTA to bees. Two concentrations of PBO $(0.05 \%$ and $0.1 \%$ PBO) were applied and two concentrations of OTA (10 and $40 \mu \mathrm{g} / \mathrm{g}$ ) were used in the bioassays. There was no indication that PBO can accelerate or delay death of bees fed OTA (Tab. I).

\subsection{Effects of propolis on the toxicity of AB1}

To determine whether propolis, as an inducer of P450s, may contribute to tolerance of mycotoxins, bioassays of bees fed with $\mathrm{AB} 1$ alone or $\mathrm{AB} 1$ and propolis extract were conducted. Bees consuming candy containing $20 \mu \mathrm{g} / \mathrm{g} \mathrm{AB} 1$ started to die after $24 \mathrm{~h}$ and all had died after $60 \mathrm{~h}$, whereas bees consuming candy containing the same concentration 


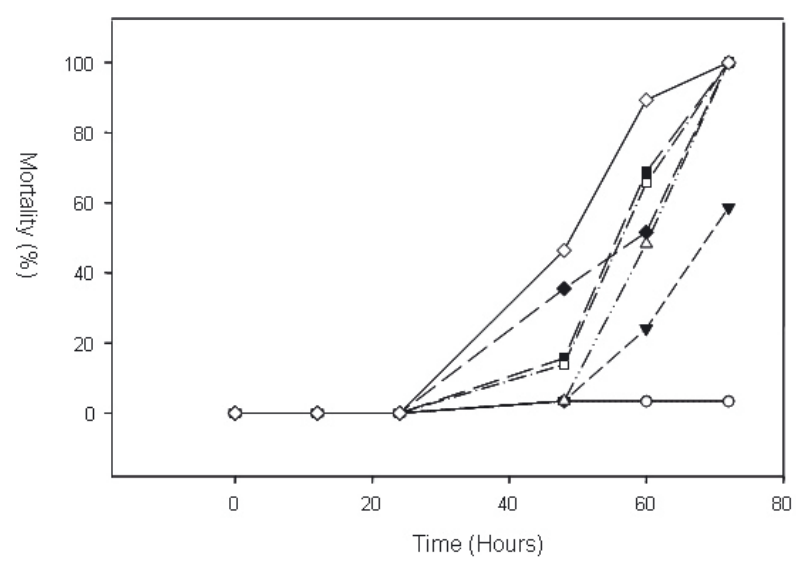

concentrations of OTA

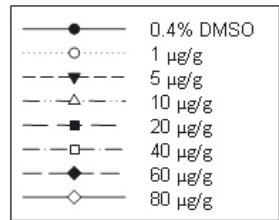

Figure 2. Mortality of Apis mellifera exposed to different concentrations of dietary ochratoxin A (OTA). Groups of approximately 30 newly eclosed workers were fed "bee candy" containing a range of concentrations of OTA in DMSO and control containing DMSO only. Each experiment was repeated three times (Tab. I); this figure graphically depicts the result of one replicate for visual clarity.

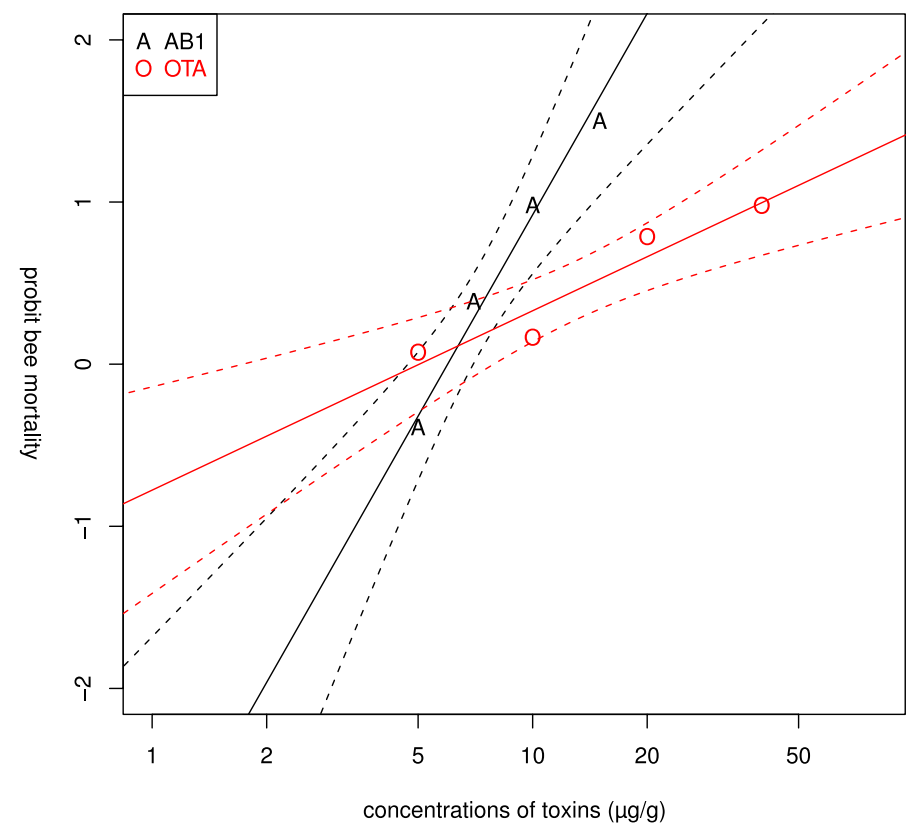

Figure 3. Comparison of $\mathrm{LC}_{50}$ of $\mathrm{AB} 1$ and OTA to bees. Plots of probits of bee mortality relative to different concentrations of $\mathrm{AB} 1$ or OTA. A (red) depicts AB1 treatments; O (black) depicts OTA treatments. $\mathrm{LC}_{50}$ is defined as the concentration of toxin that can cause $50 \%$ mortality in the tested bees after $72 \mathrm{~h}$. Each experiment was repeated three times and the estimated $\mathrm{LC}_{50}$ is the average of three replicates. The calculated $\mathrm{LC}_{50}$ for $\mathrm{AB} 1$ and OTA are $6.79 \mu \mathrm{g} / \mathrm{g}$ and $5.04 \mu \mathrm{g} / \mathrm{g}$. 
Table I. Survival analysis of effects of piperonyl butoxide (PBO) on toxicity of AB1 (aflatoxin B1) or OTA (ochratoxin A) to bees. Bioassays were conducted to compare survival time of groups of bees fed mycotoxins in the presence and absence of PBO. Estimated median survival time of bees fed "candy" containing $10 \mu \mathrm{g} / \mathrm{g} \mathrm{AB} 1,10 \mu \mathrm{g} / \mathrm{g}$ or $40 \mu \mathrm{g} / \mathrm{g}$ OTA, $0.05 \% \mathrm{PBO}, 0.1 \% \mathrm{PBO}, 10 \mu \mathrm{g} / \mathrm{g}$ AB1 supplemented with $0.05 \% \mathrm{PBO}$ or $0.1 \% \mathrm{PBO}, 10 \mu \mathrm{g} / \mathrm{g}$ or $40 \mu \mathrm{g} / \mathrm{g}$ OTA supplemented with $0.05 \% \mathrm{PBO}$ or $0.1 \% \mathrm{PBO}$ is the average of three replicates. Treatments of PBO plus toxin that differ significantly from toxin alone are indicated with “*” $(P<0.05)$.

\begin{tabular}{lcc}
\hline Treatment & Median survival time (hours) & Error \\
\hline $0.1 \%$ DMSO & 186 & 25 \\
$0.05 \%$ PBO & 154 & 19 \\
$0.10 \%$ PBO & 168 & 6 \\
$10 \mu \mathrm{g} / \mathrm{g} \mathrm{AB} 1$ & 66 & 17 \\
$0.05 \%$ PBO $+10 \mu \mathrm{g} / \mathrm{g} \mathrm{AB} 1$ & $39 *$ & 4 \\
$0.10 \%$ PBO $+10 \mu \mathrm{g} / \mathrm{g} \mathrm{AB} 1$ & $39 *$ & 4 \\
$10 \mu \mathrm{g} / \mathrm{g}$ OTA & 75 & 4 \\
$0.05 \%$ PBO $+10 \mu \mathrm{g} / \mathrm{g}$ OTA & 72 & 0 \\
$0.10 \%$ PBO $+10 \mu \mathrm{g} / \mathrm{g}$ OTA & 72 & 8 \\
$40 \mu \mathrm{g} / \mathrm{g}$ OTA & 57 & 4 \\
$0.05 \%$ PBO $+40 \mu \mathrm{g} / \mathrm{g}$ OTA & 60 & 0 \\
$0.10 \%$ PBO $+40 \mu \mathrm{g} / \mathrm{g}$ OTA & 60 & 0 \\
\hline
\end{tabular}

of $\mathrm{AB} 1$ supplemented with any amount of propolis lived longer than bees fed with $\mathrm{AB} 1$ alone; fewer than $10 \%$ of bees died in $60 \mathrm{~h}$ (data not shown). Survival analysis shows that the median survival time of bees fed with $20 \mu \mathrm{g} / \mathrm{g}$ AB1 is $44 \mathrm{~h}$ while that of bees fed with candy containing $20 \mu \mathrm{g} / \mathrm{g}$ AB1 plus 50, 150 or $300 \mathrm{mg} / \mathrm{g}$ propolis is 126,150 and $154 \mathrm{~h}$, respectively. There is a significant difference in survival time between bees treated with $\mathrm{AB} 1$ and those treated with $\mathrm{AB} 1$ and propolis (Tab. II). Longer median survival time with higher concentrations of propolis (150 mg/g and $300 \mathrm{mg} / \mathrm{g}$ ) suggests a dosagedependent ameliorative effect of propolis on $\mathrm{AB} 1$ toxicity.

\section{DISCUSSION}

As repositories of large quantities of food resources maintained under conditions of high relative humidities and temperatures, beehives are particularly vulnerable to opportunistic fungal infections. Given the frequency with which fungi such as Aspergillus colonize such environments, the relative tolerance that $A$. mellifera displays to mycotoxins such as $\mathrm{AB} 1$ and OTA is ecologically consistent with the likelihood of exposure. Similarly, Helicoverpa $z e a$, the corn earworm, which only intermittently encounters aflatoxins in its preferred foodplants, displays substantially greater sensitivity to $\mathrm{AB} 1$ than does Amyelois transitella, the navel orangeworm, which routinely (and possibly preferentially) consumes fungus-contaminated plant food.

How A. mellifera tolerates mycotoxins such as aflatoxins and ochratoxins has not yet been determined definitively. In aflatoxintolerant species such as $H$. zea and $A$. transitella, metabolism of $\mathrm{AB} 1$ to non-toxic products is mediated by cytochrome $\mathrm{P} 450$ monooxygenases (Niu et al., 2008); in species that are less tolerant, such as Drosophila melanogaster, P450-mediated metabolism appears to result in epoxidation and hence bioactivation, or enhanced toxicity (Saner et al., 1995). That administration of PBO in the presence of aflatoxin increased its toxicity suggests that the honeybee, like the aflatoxintolerant $H$. zea and A. transitella, transforms these compounds to nontoxic metabolites via P450-mediated metabolism. Recent work by Johnson et al. (2009) indicates that the organophosphate coumaphos is also metabolized via P450s in bees to nontoxic products, rather than bioactivated to the more toxic oxon metabolite, as is the case for most insects. 
Table II. Survival analysis of effects of propolis on toxicity of aflatoxin B1 (AB1) to bees. Bioassays were conducted to compare survival time of groups of bees fed mycotoxins in the presence of different concentrations of propolis. Estimated median survival time of bees fed "candy" containing $20 \mu \mathrm{g} / \mathrm{g} \mathrm{AB} 1,50 \mathrm{mg} / \mathrm{g}$, $150 \mathrm{mg} / \mathrm{g}$ and $300 \mathrm{mg} / \mathrm{g}$ propolis, and $20 \mu \mathrm{g} / \mathrm{g} \mathrm{AB} 1$ supplemented with either of $50 \mathrm{mg} / \mathrm{g}, 150 \mathrm{mg} / \mathrm{g}$ or $300 \mathrm{mg} / \mathrm{g}$ propolis is the average of three replicates. Survival times for groups feeding on propolis and AB1 that are significantly different from survival time of groups consuming AB1 alone are indicated with "**”.

\begin{tabular}{lcc}
\hline Treatment & Median survival time (hours) & Error \\
\hline $0.1 \%$ DMSO & 197 & 6 \\
$50 \mathrm{mg} / \mathrm{g}$ propolis & 154 & 3 \\
$150 \mathrm{mg} / \mathrm{g}$ propolis & 168 & 12 \\
$300 \mathrm{mg} / \mathrm{g}$ propolis & 66 & 3 \\
$20 \mu \mathrm{g} / \mathrm{g} \mathrm{AB} 1$ & 44 & 3 \\
$50 \mathrm{mg}$ propolis $+\mathrm{AB} 1$ & $126^{*}$ & 21 \\
$150 \mathrm{mg}$ propolis $+\mathrm{AB} 1$ & $150^{*}$ & 8 \\
$300 \mathrm{mg}$ propolis $+\mathrm{AB} 1$ & $154^{*}$ & 18 \\
$0.10 \%$ PBO $+10 \mu \mathrm{g} / \mathrm{g}$ OTA & 72 & 8 \\
\hline
\end{tabular}

Ochratoxins are also produced by fungi that can be found in hive products (Gilliam et al., 1989). We found that, although workers can tolerate low levels of OTA $(1 \mu \mathrm{g} / \mathrm{g})$, concentrations higher than $5 \mu \mathrm{g} / \mathrm{g}$ will kill over $50 \%$ of exposed bees in 3 days under bioassay conditions. To date, no studies have been published on OTA metabolism by insects. Although metabolism of OTA in mammals is mediated primarily by P450s (Neal, 1995), the fact that, in our study, PBO has no effects on OTA toxicity suggests that this enzyme system might not be involved in the detoxification of OTA in honeybees. Studies with synergists must be interpreted cautiously, however, inasmuch as PBO does not necessarily inhibit all P450-mediated transformations in insects (Sanchez-Arroyo et al., 2001).

Propolis, prepared from resinous materials collected from plants by honeybees, is thought to function principally as a sealant for gaps within the hive to enhance structural stability (Burdock, 1998; Bankova, 2005). It also plays a key role in reducing decay of extraneous organic material within the hive and may also help bees fend off parasites and pathogens. Its antimicrobial activity is attributed to its high content of flavonoids and phenolics and in fact propolis extracts in vitro can inhibit the growth of fungi, including Aspergillus versicolor, A. flavus, A. sulphureus and A. parasiticus, and suppress production of mycotoxins, including AB1, OTA and sterigmatocystin (Aly and Elewa, 2007; Gómez-Caravaca et al., 2006; Ozcan, 2004; Pepeljnjak et al. 1982; Viuda-Martos et al., 2008). Simone et al. (2009) recently showed that exposure to propolis extracts downregulates expression of two honeybee immunefunction genes concomitant with lowering the eubacterial loads, suggesting that propolis in the hive may reduce the need for immune gene expression by reducing bacterial loads.

That propolis may contribute to honeybee defense against fungi and their associated toxins not only by suppressing microbe growth but also by enhancing detoxification enzymes is a novel hypothesis consistent with the results of our study, at least with respect to AB1. Of the $46 \mathrm{P} 450$ s that are found in the honeybee genome, several in the CYP6AS subfamily are selectively induced by hive products such as honey, pollen and propolis, indicating a possible role in xenobiotic detoxification (Johnson, 2008). Indeed, Mao et al. (2009) demonstrated that CYP6AS3 is capable of metabolically transforming quercetin, a flavonoid found in propolis and in a wide variety of honeys. The ability of propolis to ameliorate the toxicity of $\mathrm{AB} 1$, as demonstrated in this study, suggests a function for propolis as an adjuvant for detoxification. Although the honeybee genome contains far fewer P450 genes than do other sequenced insect genomes, bees may compensate for reduced numbers by efficiently regulating the expression of a small number of 
P450s for detoxification by induction with dietary phytochemicals. Individual P450s might be greatly induced by propolis extracts to biotransform $\mathrm{AB} 1$ into less toxic compounds, thereby reducing the risks of exposure to mycotoxins.

Propolis has long been used in traditional medicine and has been credited with immunomodulatory, anti-inflammatory and antimicrobial activity. At least some of the therapeutic activity of propolis in alternative medicine has been attributed to its function as an inducer of cytochrome P450 monooxygenase activity (Bhaudauria et al., 2007). Propolis treatment has been shown to increase activities of a range of $\mathrm{P} 450 \mathrm{~s}$, including pentoxyresorufin depentylase, and ethoxycoumarin deethylase (Siess et al. 1996). More recently, BeltránRamírez et al. (2008) reported that caffeic acid phenethyl ester, a common constituent of propolis, can modify expression of multiple P450s to inhibit the activation of diethylnitrosamine in rats. To some extent, it is remarkable that the body of knowledge relating to the biochemical activity of propolis in human health is substantially larger than that relating to the biochemical activity of propolis in honeybee health; a greater understanding of the multiple roles of propolis in the life of the honeybee can be gained by further study of the ways in which it is processed and metabolized.

\section{ACKNOWLEDGEMENTS}

This work was supported by USDA grant AG2008-3532-18831. We thank Dr. Gene Robinson for access to and assistance with honeybees.

Toxicité des mycotoxines pour les abeilles et atténuation de cette toxicité grâce à la propolis.

\section{Abeille / aflatoxine B1 / ochratoxine A / cyto- chrome $\mathbf{P 4 5 0}$ / monooxygénase / butoxide de pi- peronyle / propolis}

\section{Zusammenfassung - Toxizität von Mycotoxinen für Honigbienen und ihre Melioration durch Propolis. Honigbienen und ihre Ressourcen- reichen Nester, die bei hoher Temperatur und Luftfeuchtigkeit gehalten werden, sind eine geeig- nete Umgebung für das Wachstum einer großen}

Vielfalt von opportunistischen Mikroorganismen. Hierzu gehören mehrere Pilzarten, die toxische Substanzen produzieren (sogenannte Mycotoxine). Die Toxizität von Aflatoxin B1 und Ochratoxin A, Produkte von häufig in Bienenvölkern gefundenen Aspergillusarten, wurden in dieser Studie bestimmt und die Konzentrationen der jeweiligen Toxine wurden berechnet, bei denen im Mittel $50 \%$ aller getesteten Bienen sterben. Arbeiterinnen können ein großes Konzentrationsspektrum beider Mycotoxine tolerieren. Bei geringen Konzentrationen waren weder Aflatoxin B1 noch Ochratoxin A giftig für die Bienen, aber höhere Konzentrationen waren nachweislich letal innerhalb von $48 \mathrm{~h}$. Insgesamt wirkt Aflatoxin B1 stärker toxisch als Ochratoxin A. Die Bienen sind offensichtlich in der Lage, Aflatoxin B1 zum Teil mit ihrem Darmenzym, Cytochrom P450 -Monooxygenase, $\mathrm{zu}$ metabolisieren. Wir schliessen das aus dem Befund, dass die Toxizität dieses Mycotoxins durch die Anwesenheit von Piperonyl-butoxid, einem Inhibitor dieses Enzyms, erhöht ist. Extrakte von Propolis, einer Mischung von Pflanzenharzen, die von Bienen als allgemeiner Kitt im Nest eingesetzt werden, verringern die Toxizität von Aflatoxin B1 und verzögern den Sterbezeitpunkt von Bienen, die das Mycotoxin aufgenommen haben. Propolis könnte eine bislang unerkannte Rolle für die Bienengesundheit spielen, indem es die Aktivität solcher Enzyme steigert, die an der Mycotoxin-Entgiftung beteiligt sind.

Honigbiene / Aflatoxin B1 / Ochratoxin A / Cytochrom-P450-Monooxygenasen / Piperonylbutoxid / Propolis

\section{REFERENCES}

Aly S.A., Elewa N.A. (2007) The effect of Egyptian honeybee propolis on the growth of Aspergillus versicolor and sterigmatocystin biosynthesis in Ras cheese, J. Dairy Res. 74, 74-78.

Bankova V. (2005) Chemical diversity of propolis and the problem of standardization, J. Ethnopharmacol. 100, 114-117.

Beltrán-Ramírez, O., Alemán-Lazarini L., SalcidoNeyoy M., Hernandez-Garcia H., Fattel-Fazenda S., Arce-Popoca E., Arellanes-Robleod J., GarciaRoman R., Vazquez-Vazquez P., Sierra-Santoya A., Villa-Trevino S. (2008) Evidence that the anticarcinogenic effect of caffeic acid phenethyl ester in the resistant hepatoccyte model involves modifications of cytochrome P450, Toxicol. Sci. 104, 100-106.

Bhaudauria M., Nirala S.K., Shukla S. (2007) Propolis protects CYP2E1 enzymatic activity and oxidative stress induced by carbon tetrachloride, Mol. Cell Biochem. 302, 215-224. 
Burdock G.A. (1998) Review of the biological properties and toxicity of bee propolis, Food Chem. Toxicol. 36, 347-363.

Finney D.J. (1971) Probit Analysis, University Press, Cambridge.

Gilliam M., Venderberg J.D. (1988) Fungi, in: Morse R.A., Nowogrodski R. (Eds.), Honeybee Pests, Predators and Diseases, Cornell University Press, Ithaca.

Gilliam M., Prest D.B., Lorenz B.J. (1989) Microbiology of pollen and bee bread: taxonomy and enzymology of molds, Apidologie 20, 53-68.

Gómez-Caravaca A.M., Gómez-Romero M., ArráezRomán D., Segura-Carretero A., FernándezGutiérrez A. (2006) Advances in the analysis of phenolic compounds in products derived from bees, J. Pharm. Biomed. Biomed. Anal. 41, 12201234.

González G., Hinojo M.J., Mateo R., Medina A., Jiménez M. (2005) Occurrence of mycotoxin producing fungi in bee pollen, Int. J. Food Microbiol. $105,1-9$.

Hilldrup J.A., Llewellyn G.C. (1979) Acute toxicity of the mycotoxin aflatoxin B1 in Apis mellifera, J. Apic. Res. 18, 217-221.

James R., Pitt-Singer T.L. (2008) Bee Pollination in Agricultural Ecosystems, Oxford University Press, New York.

Jimenez M., Mateo J.J., Huerta T., Mateo R. (1994) Influences of the storage conditions on some physicochemical and mycological parameters of honey, J. Sci. Food Agric. 64, 67-74.

Johnson R.M. (2008) Toxicogenomics of Apis mellifera, Doctoral dissertation, University of Illinois Urbana-Champaign.

Johnson R.M., Pollock H.S., Berenbaum M.R. (2009) Synergistic interactions between in-hive miticides in Apis mellifera, J. Econ. Entomol. 102, 474-479.

Johnson R.M., Wen Z., Schuler M.A., Berenbaum M.R. (2006) Mediation of pyrethroid insecticide toxicity to honeybees (Hymenoptera: Apidae) by cytochrome P450 monooxygenases, J. Econ. Entomol. 99, 1046-1050.

Lee S.E, Campbell B.C. (2000) In vitro metabolism of aflatoxin B1 by larvae of navel orangeworm, Amyelois transitella (Walker) (Insecta, Lepidoptera, Pyralidae) and codling moth, Cydia pomonella (L.) (Insecta, Lepidoptera, Tortricidae), Arch. Insect Biochem. Physiol. 45, 166-174.

Li X., Schuler M.A., Berenbaum M.R. (2007) Molecular mechanisms of metabolic resistance to synthetic and natural xenobiotics, Annu. Rev. Entomol. 51, 231-253.

Mao W., Johnson R., Schuler M.A., Berenbaum M.R. (2009) CYP6AS3, a quercetin-metabolizing cytochrome P450 monooxygenase in Apis mellifera, Comp. Biochem. Physiol. Part C 154, 427-434.

Martins H.M., Martins M.L., Bernardo F.M.A. (2003) Bacillaceae spores, fungi and aflatoxins determined in honey Esporos de Bacillaceae, fungos e aflatoxinas em mel, Rev. Port Ciências Veterinarias 98, 85-88.

Medina A., Gonzalez G., Saez J., Mateo R., Jimenez M. (2004) Bee pollen, a substrate that stimulates ochratoxin A production by Aspergillus ochraceus Wilh., Syst. Appl. Microbiol. 27, 261-267.

Neal G.E. (1995) Genetic implications in the metabolism and toxicity of mycotoxins, Toxicol. Lett. 82-83, 861-867.

Niu G., Siegel J., Schuler M.A., Berenbaum M.R. (2009) Comparative toxicity of mycotoxins to navel orangeworm (Amyelois transitella) and corn earworm (Helicoverpa zea), J. Chem. Ecol. 35, 951-7.

Niu G., Wen Z., Rupasinghe S.G., Zeng R.S., Berenbaum M.R., Schuler M.A. (2008) Aflatoxin B1 detoxification by CYP321A1 in Helicoverpa zea, Arch. Insect Biochem. Physiol. 69, 32-45.

Ozcan M. (2004) Inhibition of Aspergillus parasiticus NRRL 2999 by pollen and propolis extracts, J. Med. Food 7, 114-116.

Palumbo J.D., Mahoney N.E., Light D.M. (2008) Navel orangeworm (Amyelois transitella) as a vector of Aspergillus flavus on almonds, Phytopathology 98, S119.

Pepeljnjak S., Jalsenjak I., Maysinger D. (1982) Inhibition of growth and biosynthesis of ochratoxin A in Aspergillus sulphureus NRRL 4077 by propolis extract, Pharmazie 37, 439-440.

R Development Core Team, (2009) R: A Language and Environment for Statistical Computing, R Foundation for Statistical Computing, Vienna, Austria.

Sanchez-Arroyo H., Koehler P.G., Valles S.M. (2001) Effects of the synergists piperonyl butoxide and S,S,S-tributyl phosphorotrithioate on propoxur pharmacokinetics in Blattella germanica (Blattodea: Blattellidae), J. Econ. Entomol. 94, 1209-1216.

Saner C., Weibel B., Wurgler F.E., Sengstag C. (1996) Metabolism of promutagens catalyzed by Drosophila melanogaster CYP6A2 enzyme in Saccharomyces cerevisiae, Environ. Mol. Mutagen. 27, 46-58.

Siess M.M., Le Bon A.M., Canivenc-Lavier M.C., Amiot M.-J., Sabatier S., Aubert S.Y., Suschetet M. (1996) Flavonoids of honey and propolis: Characterization and effects on hepatic drugmetabolizing enzymes and benzo[a]pyrene-DNA binding in rats, J. Agric. Food Chem. 44, $2297-$ 2301.

Simone M., Evans J.D., Spivak M. (2009) Resin collection and social immunity in honeybees, Evolution 63, 3016-3022.

Venables W.N., Ripley B. (2002) Modern Applied Statistics with S, Springer, New York.

Viuda-Martos, M., Nuiz-Navajas, Y., FernandezLopez, J., Perez-Alvarez, J.A. (2008) Functional properties of honey, propolis, and royal jelly, J. Food Sci. 73, R117-R124. 